2013-08

\title{
Responses of marine benthic microalgae to elevated $\mathrm{CO} 2$
}

\author{
Johnson, VR
}

http://hdl.handle.net/10026.1/2890

10.1007/s00227-011-1840-2

Marine Biology

Springer Science and Business Media LLC

All content in PEARL is protected by copyright law. Author manuscripts are made available in accordance with publisher policies. Please cite only the published version using the details provided on the item record or document. In the absence of an open licence (e.g. Creative Commons), permissions for further reuse of content should be sought from the publisher or author. 


\title{
Responses of marine benthic microalgae to elevated $\mathrm{CO}_{2}$
}

\author{
V. R. Johnson - C. Brownlee • R. E. M. Rickaby • \\ M. Graziano • M. Milazzo • J. M. Hall-Spencer
}

Received: 2 September 2011/ Accepted: 9 November 2011

(C) Springer-Verlag 2011

\begin{abstract}
Increasing anthropogenic $\mathrm{CO}_{2}$ emissions to the atmosphere are causing a rise in $p \mathrm{CO}_{2}$ concentrations in the ocean surface and lowering $\mathrm{pH}$. To predict the effects of these changes, we need to improve our understanding of the responses of marine primary producers since these drive biogeochemical cycles and profoundly affect the structure and function of benthic habitats. The effects of increasing $\mathrm{CO}_{2}$ levels on the colonisation of artificial substrata by microalgal assemblages (periphyton) were examined across a $\mathrm{CO}_{2}$ gradient off the volcanic island of Vulcano (NE Sicily). We show that periphyton communities altered significantly as $\mathrm{CO}_{2}$ concentrations increased. $\mathrm{CO}_{2}$ enrichment caused significant increases in chlorophyll $a$ concentrations and in diatom abundance although we did
\end{abstract}

Communicated by S. Dupont.

V. R. Johnson · J. M. Hall-Spencer ( $\varangle)$

Marine Biology and Ecology Research Centre, Marine Institute,

University of Plymouth, Plymouth PL4 8AA, UK

e-mail: jhall-spencer@plymouth.ac.uk

C. Brownlee

The Marine Biological Association of the United Kingdom (MBA), The Laboratory, Citadel Hill, Plymouth PL1 2PB, UK

R. E. M. Rickaby

Department of Earth Sciences, University of Oxford,

Parks Road, Oxford OX1 3PR, UK

M. Graziano

CNR-Institute of Atmospheric Pollution Research,

UNICAL-Polifunzionale, 87036 Rende, Italy

M. Graziano · M. Milazzo

Dipartimento di Scienze della Terra e del Mare,

University of Palermo, via Archirafi 28,

90123 Palermo, Italy not detect any changes in cyanobacteria. SEM analysis revealed major shifts in diatom assemblage composition as $\mathrm{CO}_{2}$ levels increased. The responses of benthic microalgae to rising anthropogenic $\mathrm{CO}_{2}$ emissions are likely to have significant ecological ramifications for coastal systems.

\section{Introduction}

Increasing atmospheric $\mathrm{CO}_{2}$ is causing unprecedented changes in seawater chemistry (National Research Council 2010) that are expected to have profound and widespread consequences for marine ecosystems since some organisms may benefit whilst many others are likely to be disadvantaged (Hall-Spencer et al. 2008; Doney et al. 2009; Kleypas and Yates 2009; Kroeker et al. 2010; Diaz-Pulido et al. 2011; Hepburn et al. 2011). The saturation state of calcium carbonate falls as ocean $\mathrm{pH}$ is lowered (Caldeira and Wickett 2003; Orr et al. 2005; IPCC 2007), so research into the effects that these chemical changes may have on primary producers has predominately focused on calcifiers (Engel et al. 2005; Langer et al. 2009; Martin and Gattuso 2009), although work is also now emerging on the effects of elevated $\mathrm{CO}_{2}$ on non-calcareous groups of algae.

The predicted changes in $\mathrm{CO}_{2}$ and bicarbonate $\left(\mathrm{HCO}_{3}{ }^{-}\right)$ availability have the potential to stimulate photosynthesis in marine photoautotrophs. In response to low ambient $\mathrm{CO}_{2}$ concentrations, most marine microalgae have evolved a carbon concentrating mechanism (CCM) to elevate concentrations at the site of carbon fixation (Beardall and Giordano 2002; Raven and Beardall 2003; Raven et al. 2011). Increases in dissolved $\mathrm{CO}_{2}$ are predicted to cause down-regulation of microalgal CCM capacity (Giordano et al. 2005; Hopkinson et al. 2011) and, given the energetic costs of CCMs (Raven 1991), will potentially allow 
more energy for other growth processes. As the carbon acquisition mechanisms and efficiencies of CCMs differ between algae, it is thought that rising $\mathrm{CO}_{2}$ will benefit different species to varying degrees (Hein and Sand-Jensen 1997; Tortell et al. 2000; Rost et al. 2003; Beardall and Raven 2004; Riebesell 2004; Fu et al. 2008b) and may result in dramatic community shifts with profound consequences for marine biogeochemistry (Hutchins et al. 2009).

Periphyton are microflora living attached to the surfaces of submerged objects (Azim et al. 2005). Periphytic communities (predominantly benthic diatoms and cyanobacteria) are major constituents of marine biofilms forming an important functional component of marine benthic ecosystems (Underwood 1984; Hill and Hawkins 1991; Thompson et al. 2004). Marine photoautotrophic biofilms contribute significantly to primary productivity (Hawkins et al. 1992; Bustamante et al. 1995), providing a main food source for a variety of grazers (Hawkins et al. 1989; Hill and Hawkins 1991; Jenkins et al. 2001). They also play important roles in determining the structure and dynamics of the overlying benthic communities by enhancing and/or inhibiting the settlement of invertebrates and macroalgal propagules (Meadows and Williams 1963; Huang and Boney 1984; Thompson et al. 1998).

The potential effects of ocean acidification on photoautotrophic biofilms and benthic microalgae have received relatively little attention (Torstensson et al. 2011; Witt et al. 2011). Research into the effects of ocean acidification on microalgae has mainly focused on planktonic species in laboratory or mesocosm experiments (Kim et al. 2006; Fu et al. 2007; Levitan et al. 2007). Several diatom species are relatively insensitive to changes in $\mathrm{pH}$ (Hinga 2002), and some oceanic diatoms show little response over a large $\mathrm{CO}_{2}$ range (Tortell et al. 1997; Burkhardt et al. 2001), although other experiments have shown positive responses of diatoms to $\mathrm{CO}_{2}$ enrichment (Riebesell et al. 1993; Burkhardt and Riebesell 1997; Burkhardt et al. 1999). Hopkinson et al. (2011) calculated that a doubling of ambient $\mathrm{CO}_{2}$ could reduce $\mathrm{CCM}$ expenditure and lead to an increase in diatom productivity as $\mathrm{CO}_{2}$ levels rise over the course of this century. Shifts in the dominance and composition of planktonic diatom assemblages with $\mathrm{CO}_{2}$ enrichment have also been revealed and attributed to taxon-specific differences in $\mathrm{CO}_{2}$ sensitivity (Tortell et al. 2002, 2008; Kim et al. 2006; Trimborn et al. 2009). There is also evidence that cyanobacterial responses to ocean acidification are species specific. Several oceanic, bloom-forming genera (Trichodesmium, Synechococcus and Crocosphaera spp.) improve resource allocation and increase their rates of photosynthesis, nitrogen fixation and growth in response to $\mathrm{CO}_{2}$ enrichment (Lu et al. 2006; Barcelos e Ramos et al. 2007; Hutchins et al. 2007; Levitan et al. 2007; Fu et al. 2007, 2008a; Kranz et al. 2009); Prochlorococcus, on the other hand, has showed little response (Fu et al. 2007).
Our current understanding of the impacts of ocean acidification on microalgal assemblages is very limited as no research has been carried out in situ and there is likely much to learn from observations in areas that are naturally enriched with $\mathrm{CO}_{2}$ (Liu et al. 2010). Short-term culture work has yielded contradictory results attributed to differences in the experimental design and control of carbonate chemistry (Iglesias-Rodriguez et al. 2008; Hurd et al. 2009). Short-term perturbation experiments can provoke stress responses (Wood et al. 2008), which may overestimate the impacts of acidification on marine organisms (Hendriks et al. 2010), do not reflect natural conditions and are unable to account for the adaptive capability of organisms. However, ocean acidification research is starting to be augmented with in situ experiments utilising areas that are naturally enriched with $\mathrm{CO}_{2}$ such as cold-water $\mathrm{CO}_{2}$ vents (Hall-Spencer et al. 2008; Fabricius et al. 2011; Rodolfo-Metalpa et al. 2011), hydrothermal vents (Couto et al. 2010; Vizzini et al. 2010; Bianchi et al. 2011) and upwelling areas (Thomsen et al. 2010). Such sites allow investigations of the ecosystem-level responses to ocean acidification although this approach has not yet considered effects on periphyton.

Here we present the results of an investigation that compared periphyton assemblages on artificial substrata installed along a coastal $\mathrm{CO}_{2}$ gradient at a shallow water cold vent system off the island of Vulcano, NE Sicily. Our aim was to test the hypothesis that periphyton assemblages respond to $\mathrm{CO}_{2}$ gradients and to characterise any changes in diatom and cyanobacteria populations to better understand the ecological effects of ocean acidification.

\section{Materials and methods}

\section{Study site}

This study was conducted between 17th September and 8th October 2010 along a stretch of rocky coast off the island of Vulcano $\left(38^{\circ} 25^{\prime} \mathrm{N}, 14^{\circ} 57^{\prime} \mathrm{E}\right)$, part of the Aeolian Island chain, NE Sicily (Fig. 1). This is a microtidal region where volcanic $\mathrm{CO}_{2}$ vent activity acidifies the seawater producing a pH gradient ranging from $\sim 8.2$ to $\sim 6.8$, running parallel to the coast. Three sites along this gradient were selected; Station 1 (S1) was located outside the vent and had a normal, relatively stable mean $\mathrm{pH}$ (8.18) representing ambient $\mathrm{CO}_{2}$ levels (Table 1) whereas $\mathrm{S} 2$ and $\mathrm{S} 3$ had widely varying but intermediate and low mean $\mathrm{pH}$ (mean $\mathrm{pH} 8.05$ and 7.49 , respectively) due to their proximity to $\mathrm{CO}_{2}$ vents. Median $\mathrm{CO}_{2}$ levels at $\mathrm{S} 2$ represent conditions forecasted for around the middle of this century (Nakićenović and Swart 2000), whilst at S3 they go beyond those expected due to ocean acidification, yet remain useful 
Fig. 1 Map of the study area, Baia di Levante (Vulcano Island), showing sampling stations $S 1, S 2$ and $S 3, \mathrm{v}=$ gas vents. Data represent the mean $\mathrm{pH}$ of each station $(n=18$ per station). The graph shows $\mathrm{pH}$ range along the $\mathrm{CO}_{2}$ gradient measured at various intervals between September 2009 and October 2010;

median $=$ horizontal line, 25 th and 75 th percentiles $=$ vertical boxes, 10th and 90th percentiles $=$ whiskers and dots $=\min / \max$ values

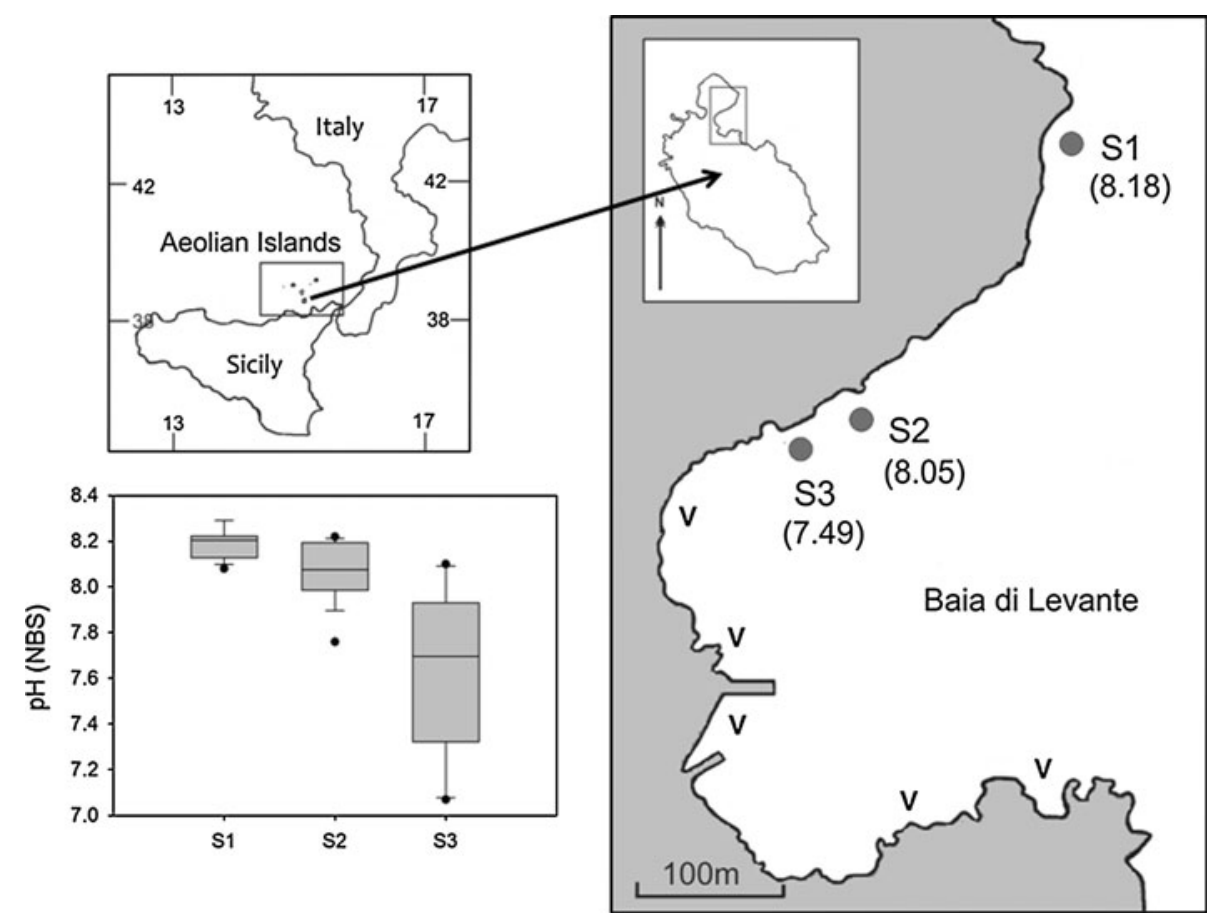

Table 1 Seawater carbonate chemistry measurements along a $\mathrm{CO}_{2}$ gradient on the island of Vulcano

\begin{tabular}{|c|c|c|c|c|c|c|c|c|c|}
\hline \multicolumn{2}{|c|}{ Station } & \multirow{2}{*}{$\begin{array}{l}\mathrm{pH} \text { range } \\
\text { (NBS scale) } \\
8.29\end{array}$} & \multirow{2}{*}{$\begin{array}{r}\begin{array}{r}p \mathrm{CO}_{2} \\
(\mu \mathrm{tm})\end{array} \\
331\end{array}$} & \multirow{2}{*}{$\begin{array}{l}\begin{array}{l}\mathrm{TA} \\
\left(\mathrm{mmol} \mathrm{kg}^{-1}\right)\end{array} \\
2.625\end{array}$} & \multirow{2}{*}{$\begin{array}{l}\begin{array}{l}\text { DIC } \\
\left(\mathrm{mmol} \mathrm{kg}^{-1}\right)\end{array} \\
2.197\end{array}$} & \multirow{2}{*}{$\begin{array}{l}\begin{array}{l}\mathrm{CO}_{3}{ }^{2-} \\
\left(\mathrm{mmol} \mathrm{kg}^{-1}\right)\end{array} \\
0.32\end{array}$} & \multirow{2}{*}{$\begin{array}{l}\begin{array}{l}\mathrm{HCO}_{3}^{-} \\
\left(\mathrm{mmol} \mathrm{kg}^{-1}\right)\end{array} \\
1.871\end{array}$} & \multirow{2}{*}{$\begin{array}{l}\Omega_{\text {calcite }} \\
7.54\end{array}$} & \multirow{2}{*}{$\frac{\Omega_{\text {aragonite }}}{7.97}$} \\
\hline $\mathrm{S} 1$ & Max & & & & & & & & \\
\hline & Median & 8.21 & 419 & & 2.233 & 0.29 & 1.929 & 7 & 4.65 \\
\hline & Min & 8.08 & 603 & & 2.339 & 0.22 & 2.101 & 5.26 & 3.77 \\
\hline \multirow[t]{3}{*}{ S2 } & Max & 8.22 & 410 & 2.642 & 2.23 & 0.31 & 1.912 & 7.38 & 4.91 \\
\hline & Median & 8.08 & 592 & & 2.401 & 0.19 & 2.193 & 4.45 & 2.89 \\
\hline & Min & 7.76 & 1,429 & & 2.512 & 0.12 & 2.349 & 2.96 & 1.96 \\
\hline \multirow[t]{3}{*}{$\mathrm{S} 3$} & Max & 8.1 & 599 & 2.736 & 2.409 & 0.25 & 2.14 & 6.05 & 4.02 \\
\hline & Median & 7.71 & 1,611 & & 2.656 & 0.1 & 2.508 & 2.28 & 1.49 \\
\hline & Min & 7.07 & 7,454 & & 2.95 & 0.02 & 2.682 & 0.54 & 0.35 \\
\hline
\end{tabular}

Temperature (range $\left.18.6-27.7^{\circ} \mathrm{C}\right), \mathrm{pH}(\mathrm{NBS}$ scale) and salinity (=38) were measured on several occasions between September 2009 and October $2010(n=18)$. Total alkalinity (TA) is point measurement taken on $02 / 10 / 10$. The remaining parameters were calculated using $\mathrm{CO}_{2} \mathrm{SYS}$ programme (using the constants of Roy et al. 1993 and Dickson for $\mathrm{KSO}_{4}$ )

for examining response boundaries (Barry et al. 2010). All stations were at ambient temperature, and although sulphur was present at the $\mathrm{CO}_{2}$ vent systems on the south of Baia di Levante, it was localised and undetectable at stations S1-S3.

Carbonate chemistry and physical measurements

At all three stations, a calibrated YSI (556 MPS) pH (NBS scale) meter was used to measure temperature, $\mathrm{pH}$ and salinity at a depth of $\sim 0.5 \mathrm{~m}$. We recorded rapid $\mathrm{pH}$ fluctuations along this coastal gradient (over 1 unit in under $\sim 4 \mathrm{~h}$ at $\mathrm{S} 3$ ), so the lack of precision in using the NBS scale for seawater measurements (approximately $0.05 \mathrm{pH}$, Dickson et al. 2007) was considered acceptable for this study. On the recommendations of Hoppe et al. (2010), total alkalinity (TA) alongside $\mathrm{pH}$ was measured to calculate carbonate chemistry. TA was measured at each station from a water sample that had been passed through a $0.2-\mu \mathrm{m}$ pore size filter (stored in the dark at $4^{\circ} \mathrm{C}$ ), and an AS-Alk 2 Total Alkalinity Titrator (Apollo SciTech Inc, Georgia, USA) was used to determine TA. The remaining parameters of the carbonate system were then calculated using $\mathrm{CO}_{2}$ SYS software (Lewis and Wallace 1998). Light intensity was measured at 1-2 m depth in May 2011 at S1 and S3 using Hobo light loggers (Onset). 
Means and interquartile ranges (IQ), more suitable for use over standard errors with highly variable $\mathrm{pH}$ data (Kerrison et al. 2011), were calculated from hydrogen ion concentrations before re-converting back to $\mathrm{pH}$ values. Means were calculated for each station using $\mathrm{pH}$ data collected from several visits to the vents between 2009 and 2010 (September-October 2009, April 2010, July 2010, September-October 2010).

\section{Sample collection}

At each station, perspex slides $(75 \times 25 \mathrm{~mm})$ were horizontally attached to four anchored floats ( 6 slides per float placed at $25-\mathrm{mm}$ intervals), suspended in the shallow subtidal zone $(<1 \mathrm{~m}$ depth) $(n=24$ slides per station). Perspex (hydrophobic surface) was selected over glass (hydrophilic) to maximise the amount of microalgal attachment (Sekar et al. 2004). The slides were removed after 21 days by which time they had established biofilms that were visible to the naked eye. Half the slides ( $n=12$ per station) were chosen randomly for chlorophyll extraction. They were immediately preserved at $-20^{\circ} \mathrm{C}$ (for $<48 \mathrm{~h}$ ) and stored at $-80^{\circ} \mathrm{C}$ upon return to the laboratory (for $<2-3$ weeks) to prevent chlorophyll degradation (Thompson et al. 1999). The remaining half were fixed in glutaraldehyde ( $2.5 \%$ with filtered seawater) for $1 \mathrm{~h}$ in the dark, rinsed and then frozen as above until epifluorescence analysis $(<1$ month) and viewing under the scanning electron microscope (SEM).

\section{Sample analysis}

The photosynthetic standing stock of each slide $(n=12$ per station) was measured from chlorophyll extracted using $100 \%$ ethanol (placed in boiling ethanol, $\sim 70^{\circ} \mathrm{C}$, for $2 \mathrm{~min}$ ). Ethanol was chosen solvent for this experiment as it is an efficient extractant of chlorophyll from resistant material and provides the most reliable estimates for use with natural assemblages of mixed microalgae (Ritchie 2008). The absorbance of each sample at 632, 649, 665, 696 and $750 \mathrm{~nm}$ was measured using a Cecil CE2011 spectrophotometer, and the concentration of the total chlorophyll $a$ (chl $a$ ) in the sample $\left(\mu \mathrm{g} \mathrm{cm}^{-2}\right)$ was calculated using the quadrichroic equation of Ritchie (2008).

The relative proportions of cyanobacteria and diatoms within the periphyton on each slide ( $n=12$ per station) was determined through quantification of their epifluorescence using confocal laser scanning microscopy (CLSM). Epifluorescence microscopy can quantify the coverage of individual components of the periphyton and is more useful than light microscopy, which only allows a limited number of cyanobacterial types to be clearly distinguished (Nagarkar and Williams 1997). In addition, diatom cells were difficult to count directly with light microscopy (thick films on some slides prevented adequate passage of light) so areal coverage of their epifluorescence was used as proxy for abundance. Slides were viewed using a Radiance 2000 CLSM (Bio-Rad, UK), excitation $488 \mathrm{~nm}$; emission $570-590 / 70,650 \mathrm{~nm}$ DCLPXR and 620-660 nm. Thirty images at a fixed, low-power magnification $(\times 10)$ were taken at random locations across each slide, and the average percentage cover of cyanobacteria and diatom fluorescence was digitally quantified using Image $\mathbf{J}$ software (v 1.43, National Institutes of Health, Bethesda, MD, USA).

The composition of the attached diatom assemblage from five replicate slides at each station was analysed by SEM. Slides were cut into $\sim 1 \mathrm{~cm}^{2}$ pieces, air-dried (Hill and Hawkins 1990) and coated with gold prior to observation with a JEOL JSM 5600 LV SEM. Each slide was examined at fixed magnification $(\times 500)$, and the abundance of different diatom genera (identified according to Round et al. 1990) was recorded from counts in ten randomly positioned photographs on the colonised areas of the slide. Diatoms that could not be accurately identified were assigned to numbered groups (i.e. unidentified pennate 1,2 , unidentified naviculoid 1).

\section{Statistical analysis}

Differences in periphyton assemblages among stations were tested using one-way ANOVA (percentage data arc $\sin$ transformed). A paired $t$ test was used to compare the differences in light intensities between S1 and S3. Data that failed tests for normality (Shapiro-Wilk) and equal variances (Levene Median test) were analysed by KruskalWallis one-way analysis of variance on ranks. Pairwise multiple comparisons were performed using Holm-Sidak method or SNK. These statistical analyses were performed using SigmaPlot 11.0.

The abundances of diatom genera were used to calculate Shannon diversity (Shannon and Weaver 1949) and Simpsons index of dominance (Simpson 1949) for each slide. The similarity of community assemblages across the different slides (total $n=15$ ) was examined by hierarchical cluster analysis using IBM SPSS Statistics 18. Only genera representing over $1 \%$ abundance were included in this analysis including any of the numbered unidentified diatoms groups. Assemblages were clustered using a dissimilarity coefficient (squared Euclidian distance) and Ward's method (minimum variance clustering).

\section{Results}

Between September 2009 and October 2010, mean surface seawater $\mathrm{pH}$ decreased with increasing proximity to $\mathrm{CO}_{2}$ vents $(\mathrm{S} 1=8.18, \mathrm{~S} 2=8.05, \mathrm{~S} 3=7.49, n=18)$ and was 
significantly different between all stations (Kruskal-Wallis test, $\left.H_{2}=34.499, P<0.001\right)$. The $\mathrm{pH}$ at $\mathrm{S} 1$ fell within the normal range of coastal waters (IQ: 8.13-8.22) whilst stations exposed to high $\mathrm{CO}_{2}$ had a greater range in $\mathrm{pH}$ that increased with proximity to the main venting area (S2 IQ: 8.00-8.19, S3 IQ: $7.36-7.89, n=18$ ). Table 1 shows the carbonate chemistry profile of each sampling station. Temperature (range $18.6-27.7^{\circ} \mathrm{C}$, April-October), salinity (38) and TA (range 2.6-2.7 $\mathrm{mmol} \mathrm{kg}^{-1}$ ) remained relatively constant among stations. The highest median values for $p \mathrm{CO}_{2}$ and DIC were found at S3 (1611 $\mu$ atm and $2.7 \mathrm{mmol} \mathrm{kg}^{-1}$, respectively), which had the lowest calcite and aragonite saturation levels (2.28 and $1.49 \Omega$, respectively). Periods of calcium carbonate under-saturation occurred during the lowest range of $\mathrm{pH}$ at $\mathrm{S} 3$ ( $\Omega$ calcite 0.54 and $\Omega$ aragonite 0.35 ). We found no significant difference in midday (noon-13:00) light intensities between $\mathrm{S} 1$ (mean lux $=36,935 \pm 3,641, n=13$ ) and S3 (mean lux $=38,895 \pm 4,234, n=13) \quad\left(t_{24}=-0.351\right.$, $P=0.729$ ). During periphyton experiments in SeptemberOctober 2010, the $\mathrm{pH}$ at S1, S2 and S3 was found to fall within the established range of the long-term data (8.26, 8.01 and 7.36, respectively), and temperature $\left(\sim 23-24^{\circ} \mathrm{C}\right)$, salinity (38) and TA (2.6-2.7 mmol kg-1) remained constant between stations.

Mean chl $a$ concentrations were significantly different between stations (ANOVA, $F_{(2,33)}=69.682, P<0.001$ ), and the highest values were measured on slides from S2 $\left(0.99 \pm 0.05 \mu \mathrm{g} \mathrm{cm}^{-2}\right)$, which were almost fivefold higher than those at $\mathrm{S} 1\left(0.19 \pm 0.03 \mu \mathrm{g} \mathrm{cm}^{-2}\right)$ (Fig. 2). Pairwise comparisons (SNK) revealed that slides from S2 and S3 had significantly greater chl $a$ concentrations than $\mathrm{S} 1$, but no significant difference could be detected between S2 and S3.

A significant difference in diatom abundance (mean \% cover on slides) was detected between stations (ANOVA, $\left.F_{(2,33)}=610.212, P<0.001\right)$; greater values were recorded with increasing $\mathrm{CO}_{2}$ levels (Holm-Sidak pairwise comparisons, $\mathrm{S} 3>\mathrm{S} 2>\mathrm{S} 1, P<0.001$ ) (Fig. 3). The highest abundances were found on slides at S3 (60 \pm
$1.11 \%)$, a sevenfold increase from S1 (8.5 $\pm 0.60 \%)$. There was no significant difference in the percentage cover of cyanobacteria in the periphtyic communities between stations (ANOVA, $F_{(2,33)}=3.041, P=0.061$ ) that remained relatively low $(<2 \%)$ across the gradient (Fig. 3$)$.

The mean diversity $\left(\mathrm{H}^{\prime}\right)$ of periphytic diatom communities was significantly different among stations (KruskalWallis test, $\left.H_{2}=7.969, P=0.019\right)$. S3 had a significantly lower diversity $(1.59 \pm 0.14)$ than the other stations whilst the diversity at $\mathrm{S} 1$ and $\mathrm{S} 2(2.3 \pm 0.11,2.2 \pm 0.28$ respectively) did not differ significantly (SNK pairwise comparisons, S2 vs. S3 $P<0.05$, S1 vs. S3 $P<0.05, \mathrm{~S} 2$ vs. S1 $P>0.05$ ) (Fig. 4). The dominance index also varied significantly between stations (ANOVA, $F_{(2,14)}=5.147$, $P=0.024)$ with significantly higher values at S3 than S1 and S2 (SNK pairwise comparisons, $0.28 \pm 0.03, \mathrm{~S} 3$ vs. S2 $P<0.05$, S3 vs. S1 $P<0.05)$. Mean values for S1 and S2 $(0.15 \pm 0.02$ and $0.18 \pm 0.08$ respectively), however, did not differ significantly (SNK pairwise comparisons, S2 vs. S1 $P<0.05)$.

Cluster analysis of relative abundances of periphytic diatom genera for each slide yielded four separate groups (Fig. 5). The slides from S1 formed widely separated, distinct groups whilst slides from S2 and S3 were more closely linked, indicating greater similarities in assemblage compositions. Figures 6 and 7 highlight the marked differences in community composition between the $\mathrm{CO}_{2}$-enriched stations (S2 and S3) and the reference station (S1). A dramatic shift in community composition occurred as the relative abundance of Toxarium and Grammatophora increased from 2.1 and $0.5 \%$, respectively, in the $\mathrm{S} 1$ assemblages to 41 and $24 \%$ in S3. Figure 8 displays mean cell counts of the most numerous taxa from the SEM images but cannot be accurately scaled-up for whole slide totals as there was a higher incidence of uncolonised spaces at S1. It shows that the changes in carbonate chemistry between S1 and S2 correlate with the growth of some genera (viz.; Toxarium, Grammatophora, Bacillaria, Navicula, Cocconeis, Amphora) whilst reducing the abundance of others (viz.; Cyclophora, Neosynedra, Rhabdonema, Nitzschia). Some
Fig. 2 Images of biofilms that colonised the slides after 3 weeks at $S 1, S 2$ and $S 3$. Chart shows chlorophyll $a$ concentration $\left(\mu \mathrm{g} \mathrm{cm}^{-2}\right)$ of colonised slides at $S 1, S 2$ and $S 3$ ( $n=12$ per station). Median $=$ horizontal line $; 25$ th and 75 th percentiles $=$ vertical boxes and 10th and 90th percentiles $=$ whiskers
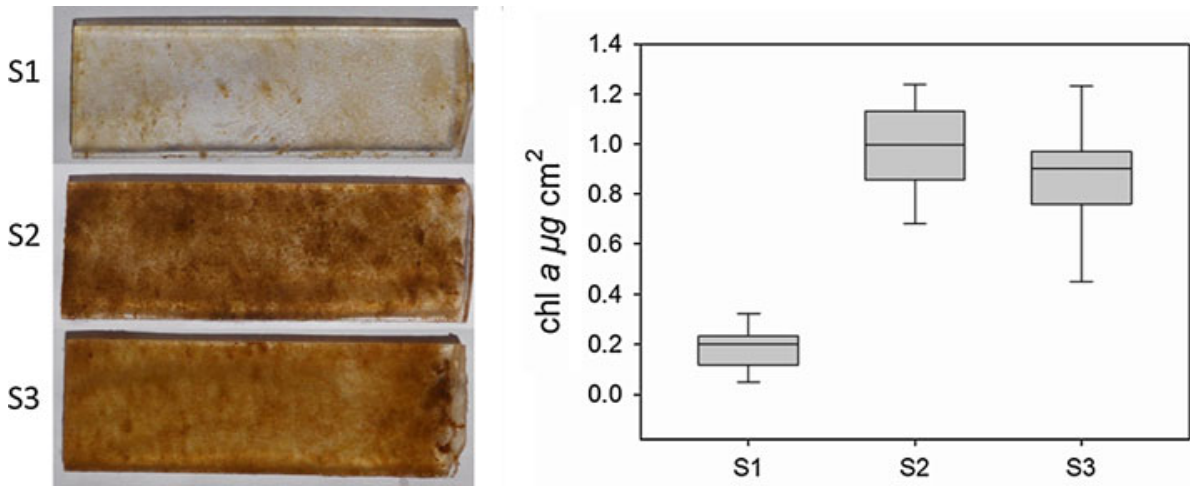
Fig. 3 Epifluorescence microscope photographs of slides colonised in S1-S3. Images show an increase in diatoms (pennates) from $S 1$ to $S 3$ whilst cyanobacteria (filamentous and coccoid) cover remains relatively low at each station (scale bars $=50 \mu \mathrm{m}$ ) $($ Red $=$ diatoms, green/ yellow $=$ cyanobacteria $)$ Graph shows relative percentage cover \pm SE (based on chlorophyll fluorescence) of cyanobacteria and diatoms along the $\mathrm{CO}_{2}$ gradient $(n=12$ per station) (colour figure online)
S1

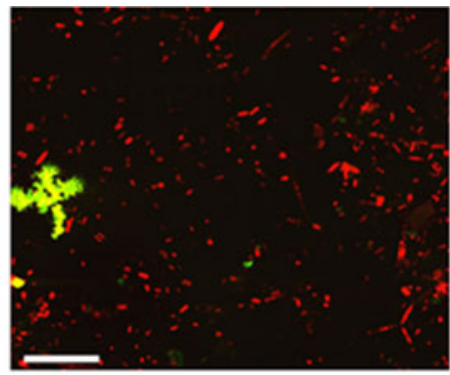

S2

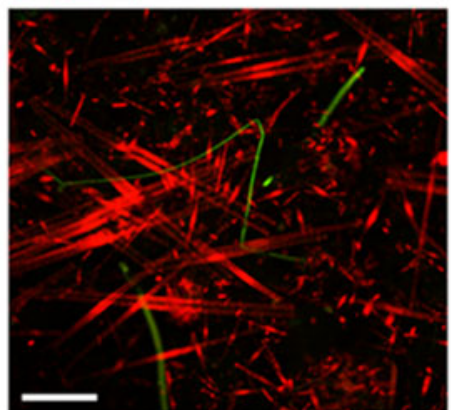

S3

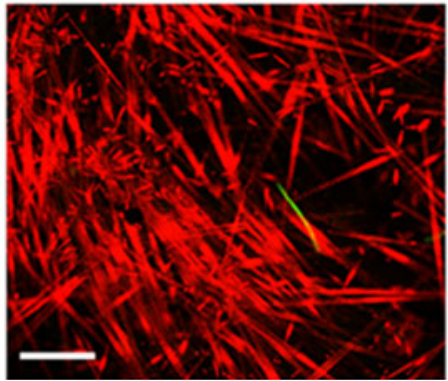

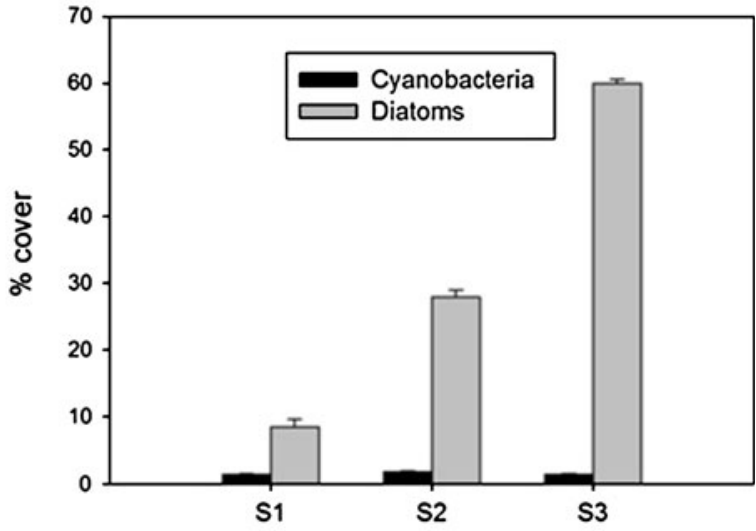

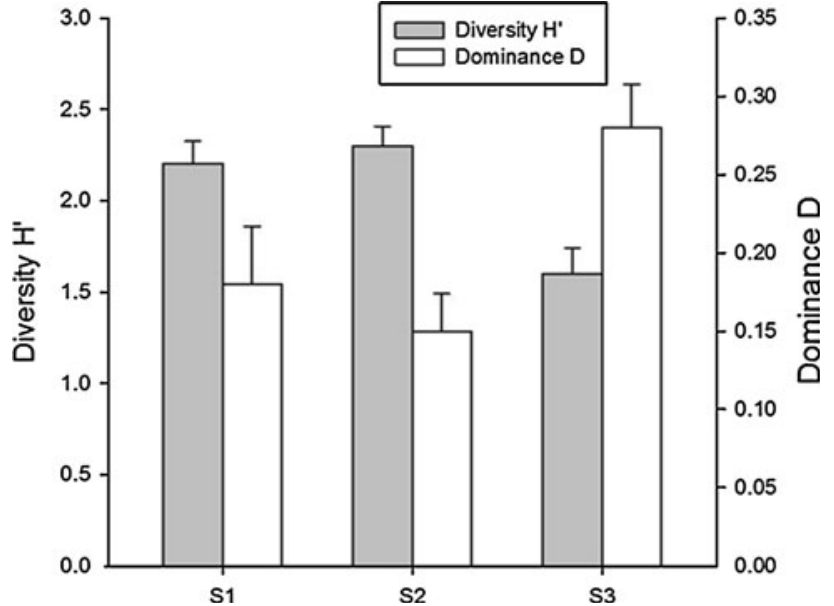

Fig. 4 Mean \pm SE values ( $n=5$ per station) for diversity (Shannon $\mathrm{H}^{\prime}$ ) and dominance (Simpsons index D) of periphytic diatom assemblages along the $\mathrm{CO}_{2}$ gradient

genera, on the other hand, did not appear to be affected by the changes in $\mathrm{pH} / \mathrm{CO}_{2}$ (viz.; Licmophora, Striatella). The subsequent changes that occurred with further elevations in $\mathrm{CO}_{2}$ at $\mathrm{S} 3$ correspond to the increased dominance of Toxarium and Grammatophora and further reductions in other genera (viz.; Striatella, Navicula, Amphora).

\section{Discussion}

There have been relatively few studies exploring the impact of $\mathrm{CO}_{2}$ enrichment on temperate benthic ecosystems, in particular the microphytobenthos. This paper presents the first assessment of the responses of periphytic assemblages to elevated $\mathrm{CO}_{2}$ in situ. In order to advance our understanding of how ocean acidification may impact coastal benthic ecosystems, it is essential to determine what changes will occur at the level of the primary producers. This field study adds to a growing body of evidence from $\mathrm{CO}_{2}$ vent sites that reveal the important biological and ecological changes that are likely to occur with increasing $\mathrm{CO}_{2}$ emissions (Martin et al. 2008; Cigliano et al. 2010; Dias et al. 2010; Rodolfo-Metalpa et al. 2010; Porzio et al. 2011; Lombardi et al. 2010).

The large $\mathrm{pH}$ variability found within the Vulcano vent zone has also been observed at other vent sites (HallSpencer et al. 2008; Kerrison et al. 2011) and is likely the result of changes in wave action and currents. This can be considered a drawback to in situ studies because accurate dose-response relationships become difficult to determine and most surface waters will not be characterised by such rapid variability as the oceans acidify (Riebesell 2008). 


\section{Distance}

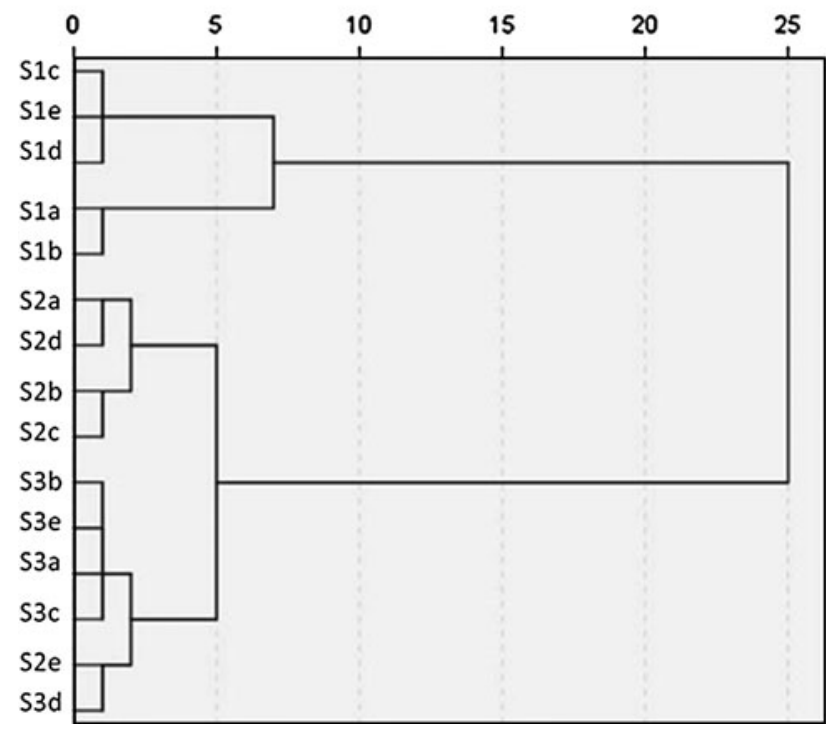

Fig. 5 Cluster analysis of the similarity of periphytic diatom assemblage composition based on Ward's method with squared Euclidian distance for all the slides sampled along the $\mathrm{CO}_{2}$ gradient ( $n=5$ per station). Analysis consists of all genera present over $1 \%$, including any of the unidentified groups

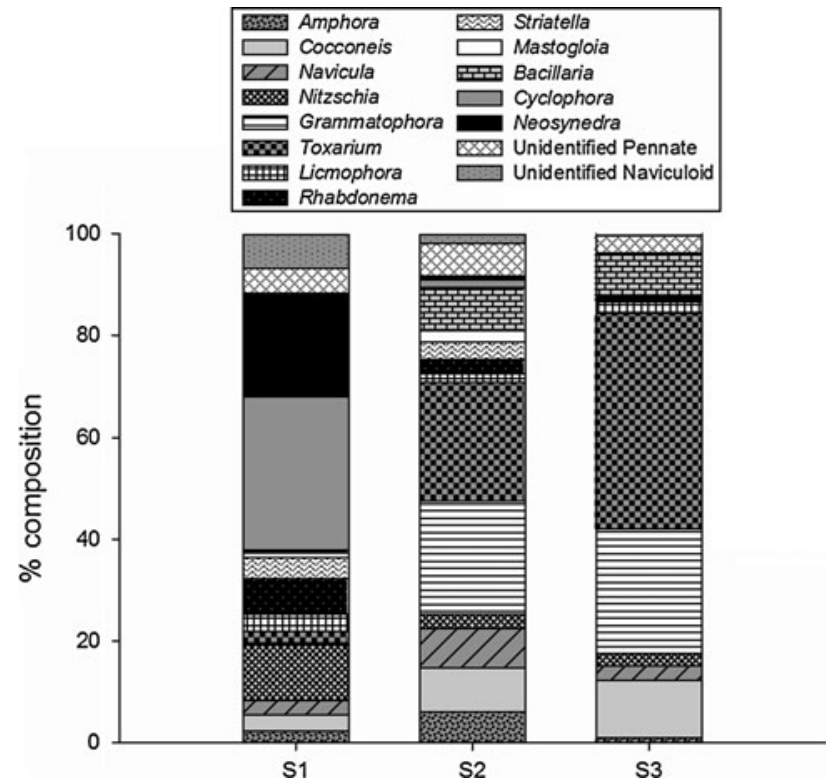

Fig. 6 Relative composition of the periphytic diatom assemblages along the $\mathrm{CO}_{2}$ gradient, including all genera present over $1 \%$ and with all unidentified diatoms grouped as unidentified pennate or naviculoid

Despite this, mean $\mathrm{pH}$ differs significantly between sampling stations so the relative changes on spatial scales yield important information about the effects of $\mathrm{CO}_{2}$ enrichment on benthic communities. Potential confounding variables such as light, temperature, total alkalinity, and salinity remained relatively constant between stations. Whilst nutrient levels have not been measured on this occasion, the relatively small size of the study area (length $\sim 300 \mathrm{~m}$ ) and lack of river outflows in the bay imply that they also should not have been a significant source of variation in the microalgal assemblages we sampled. The biomass of phototrophic biofilm biomass is known to be regulated by grazing gastropods (Hill and Hawkins 1991; Mak and Williams 1999; Stafford and Davies 2005), populations of which have been found to decrease at low $\mathrm{pH}$ at other $\mathrm{CO}_{2}$ vent systems (Hall-Spencer et al. 2008). The design of the experimental slides in this study, however, eliminates this as a potential confounding factor as the floats to which they were attached were suspended above the benthos (via thin nylon wire), out of the influence of macroinvertebrate grazing.

By using chl $a$ as an index of the photosynthetic standing crop (Underwood 1984), periphyton biomass was found to increase substantially (fivefold) at the $\mathrm{CO}_{2}$-enriched stations. This indicates that elevations in $\mathrm{CO}_{2}$ stimulate primary productivity in these benthic assemblages. Diatom epifluorescence increased significantly across all stations with increasing $\mathrm{CO}_{2}$ concentrations, with a sevenfold difference between $\mathrm{S} 1$ and $\mathrm{S} 3$ station. This appears to be attributed to the increase in abundance of large pennate types. A potential methodological shortcoming, however, must be addressed here; epifluorescence measurements, despite providing useful percentage surface cover data, may not yield accurate information concerning the vertical density of the biofilm. The self-shading effects that can occur within thicker biofilms (McNamara and Hill 2000) may be source of variance in chl $a$ measurements, and the reduced light intensity has the potential to induce higher concentrations without the corresponding increase in biomass. In addition, as $\mathrm{pH}$ may vary in different layers of a biofilm, future studies should incorporate the use of $\mathrm{pH}$ microelectrodes to measure the potential gradient through the microalgal layers.

Laboratory studies have revealed that $\mathrm{pH}$ can affect the adhesion of diatoms to hard surfaces; however, attachment is reportedly favoured in more alkaline conditions greater than pH 7 (Sekar et al. 2004). The greater abundance of diatoms at S2 and S3 is therefore not likely to be the result of $\mathrm{pH}$-induced preferential attachment. Our data contradict the results of some previous experiments on benthic and planktonic diatom species that suggest their responses to ocean $\mathrm{pH}$ changes will be negative (Torstensson et al. 2011) or small (Tortell et al. 1997, 2000; Burkhardt et al. 1999). Our data support the notion that some diatoms will benefit from increasing $\mathrm{CO}_{2}$ through a reduction in the energetic costs of their CCMs, optimising resource allocation (Beardall and Giordano 2002; Rost et al. 2008; Trimborn et al. 2009; Hopkinson et al. 2011). These results are also in agreement with field incubations that showed $\mathrm{CO}_{2}$ stimulation of phytoplanktonic communities (Tortell 
1a

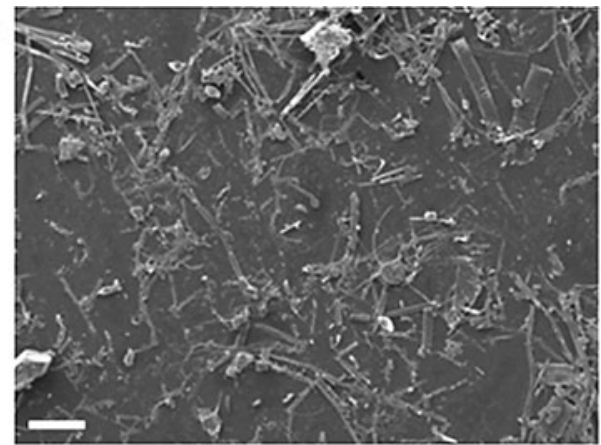

2a

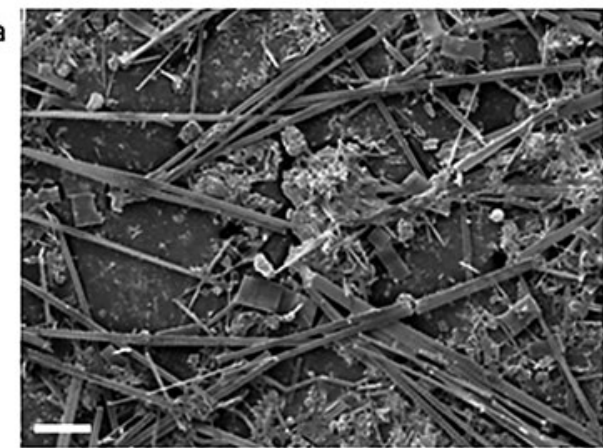

3a

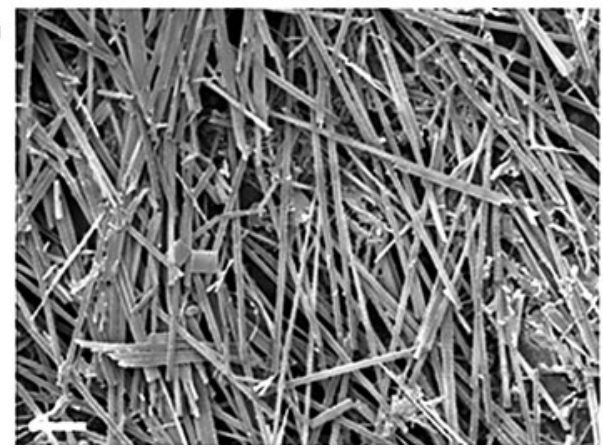

Fig. 7 SEM images of slides colonised by periphytic diatoms at the three stations; S1 (1a, 1b), S2 (2a, 2b) and S3 (3a, 3b). Diatom colonisation increases with rising $p \mathrm{CO}_{2}$ concentrations along the gradient (1a, 2a, 3a). Changes in the community composition also

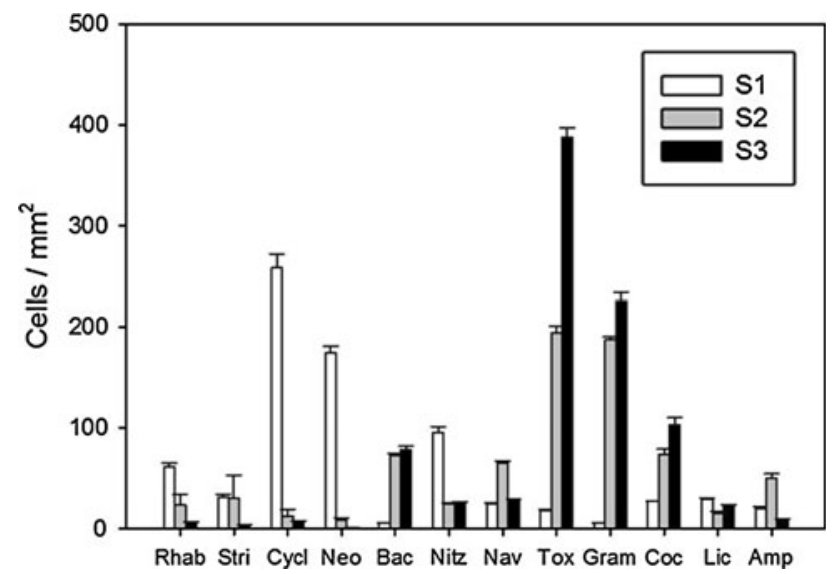

Fig. 8 Changes in the mean diatom abundances between $S 1, S 2$ and S3; error bars represent standard error ( $n=5$ per station)

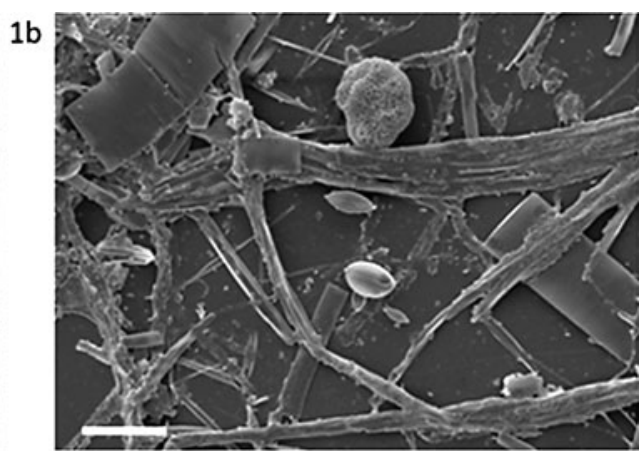

$2 \mathrm{~b}$

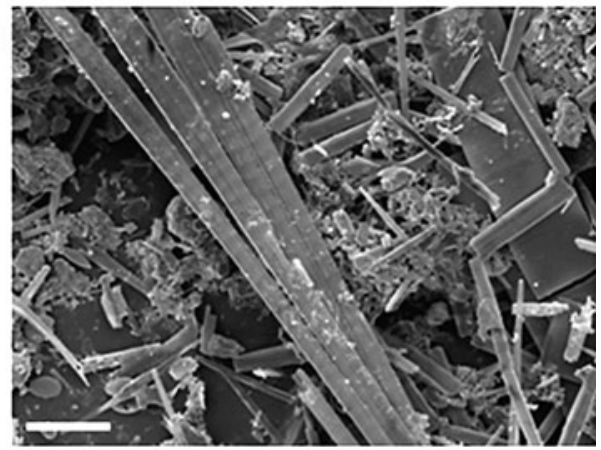

$3 \mathrm{~b}$

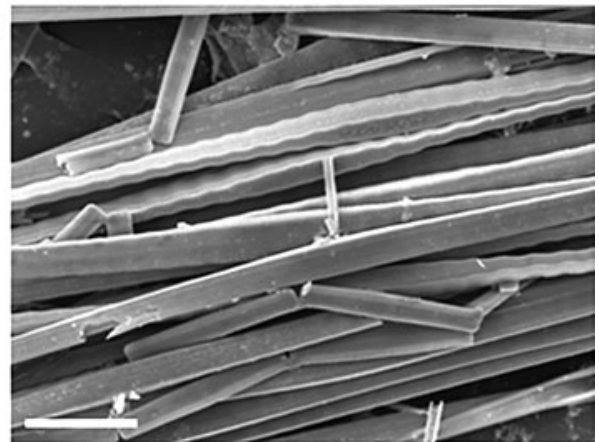

occur with colonies of Grammatophora spp. and Toxarium undulatum dominating in S2 and S3 (2b, 3b) (Scale bars: 1a, 2a, $2 \mathbf{b}=100 \mu \mathrm{m}$, $\mathbf{1 b}, \mathbf{2 b}, \mathbf{3 b}=50 \mu \mathrm{m})$

et al. 2002, 2008) and support the findings from a recent biofilm laboratory experiment which observed a promotion of diatom dominated biofilms in high $\mathrm{CO}_{2}$ treatments (Witt et al. 2011). Our epifluorescence findings indicate that periphytic diatoms, rather than cyanobacteria, were responsible for the differences measured in chl $a$ concentrations and strongly indicate that $\mathrm{CO}_{2}$ enrichment may stimulate the growth of temperate benthic diatoms.

Experimental studies of bloom-forming cyanobacteria usually show a positive response to $\mathrm{CO}_{2}$ enrichment (Barcelos e Ramos et al. 2007; Hutchins et al. 2007; Levitan et al. 2007; Fu et al. 2008a; Kranz et al. 2009). We did not record this response as cyanobacteria coverage on the slides remained low $(<2 \%)$ at each station. This is consistent with reports of highly efficient CCMs in cyanobacteria (Badger and Price 2002). A similar neutral 
response to elevated $\mathrm{CO}_{2}$ has also been observed in endolithic cyanobacteria (Tribollet et al. 2006). Primary production saturation under ambient $p \mathrm{CO}_{2}$, attributed to $\mathrm{CCM}$ activity or oligotrophic conditions, limiting production was thought to underlie this response and may also apply to the Mediterranean cyanobacteria assemblages of the present study. It can be assumed that the reduction in $\mathrm{pH}$ at the $\mathrm{CO}_{2}$-enriched stations does not limit cell attachment as several laboratory studies have shown that $\sim \mathrm{pH} 7$ creates favourable conditions for cyanobacteria adhesion (Stanley 1983; Vanhaecke et al. 1990; Matsumoto et al. 2000).

The majority of the diatom genera that colonised the slides were the attached forms, araphid and monoraphid groups (e.g. Cocconeis, Amphora, Toxarium, Grammatophora, Cyclophora); however, free-living motile forms, pennate biraphids, were also present within the biofilms (e.g. Nitzschia, Navicula). SEM analysis of the composition of diatom populations revealed two contrasting assemblages between $\mathrm{S} 1$ and the $\mathrm{CO}_{2}$-enriched stations ( $\mathrm{S} 2 \& \mathrm{~S} 3$ ). The changes in carbonate chemistry caused some populations to increase whilst others decreased. Whilst this indicates a shift in competitive outcomes and assemblage structure, it only applies for the genera identified; species-specific changes in these populations need to be investigated further. Diversity was significantly reduced at $\mathrm{S} 3$. As $\mathrm{CO}_{2}$ concentrations increased, large and chain-forming pennates (Toxarium and Grammatophora) began to dominate the periphyton assemblages. Similar results have also been found in Southern Ocean phytoplankton assemblages where elevated $\mathrm{CO}_{2}$ conditions promoted a shift to larger chain-forming Chaetoceros spp. (Tortell et al. 2008). The authors attributed this to differences in surface area to volume ratios between genera that would influence competitive outcomes under increasing $\mathrm{CO}_{2}$ concentrations. Diffusion limitation becomes increasingly important as cell size increases (Chisholm 1992; Kiørboe 1993), under present $\mathrm{CO}_{2}$ conditions carbon uptake in smaller species is maximised by high surface area to volume ratio whilst larger species (which have smaller surface area to volume ratios and longer diffusion paths) are at a competitive disadvantage. Elevations in $\mathrm{CO}_{2}$ levels may therefore change the competitive abilities among different size classes of diatoms.

Our findings indicate that periphytic diatoms exhibit a non-uniform response to $\mathrm{CO}_{2}$ enrichment; this is most likely due to taxon-specific differences in their sensitivity to $\mathrm{CO}_{2}$ concentrations and presumably due to their kinetics of carbon use. $\mathrm{CO}_{2}$-induced community shifts have also been observed in many other photoautotrophic assemblages (Tortell et al. 2002, 2008; Fu et al. 2007; Russell et al. 2009; Trimborn et al. 2009; Connell and Russell 2010; Porzio et al. 2011) adding to evidence that increasing $\mathrm{CO}_{2}$ emissions are likely to lead to structural and functional changes in a wide variety of marine and coastal systems. The establishment of microalgal assemblages on artificial substrata is a complex process. Differences in seasonal recolonisation and succession events (Anderson 1995; Munda 2005) and artificial substratum type (Tuchman and Blinn 1979; Edyvean et al. 1985; Sekar et al. 2004) play an important part in determining the final periphyton assemblage. The diatom composition data presented in this study therefore provides an indication of elevated $\mathrm{CO}_{2}$ effects on biofilm assemblages rather than a precise analogue for the future effects of $\mathrm{CO}_{2}$ enrichment. Similar studies should be repeated seasonally, using a variety of substrata and based across different $\mathrm{CO}_{2}$ gradients to better constrain the large-scale changes that we can expect in response to increases in $\mathrm{CO}_{2}$ emissions.

The periphyton assemblages analysed here showed significant changes resulting from $\mathrm{CO}_{2}$ enrichment. We confirm that increasing $\mathrm{CO}_{2}$ can stimulate the growth of some benthic diatom species, particularly large, chain-forming genera, promoting the primary productivity in shallow water coastal habitats. This is likely to have wide-ranging consequences from local-scale influences on the structure of overlying benthic communities to effects on food web structure and larger-scale biogeochemical cycles.

Acknowledgments $\mathrm{VJ}$ is carrying out a $\mathrm{PhD}$ funded by the Marine Institute, University of Plymouth (UoP) and thanks are due to the staff at the Marine Biological Association, UK and the SEM unit at UoP for laboratory support. We also thank C. Totti and T. Romagnoli at Università Politecnica delle Marche, Ancona, Italy for assistance with diatom identification, R. Lee at the Department of Earth Sciences at Oxford University for help with fieldwork, Y. Olsen and L. Basso at IMEDEA, Spain for providing light data and A. Beesley at Plymouth Marine Laboratory for performing total alkalinity analysis. This article contributes to the EU FP7 project on 'Mediterranean Sea Acidification under a changing climate' (MedSeA grant agreement no. 265103) and to the UK Ocean Acidification Research Programme, with additional funding for JHS from Save Our Seas Foundation and for RR from ERC grant SP2-GA-2008-200915.

\section{References}

Anderson MJ (1995) Variations in biofilms colonising artificial surfaces: seasonal effects and effects of grazers. J Mar Biol Assoc UK 75:705-714

Azim ME, Verdegem MCJ, van Dam AA, Beveridge MCM (eds) (2005) Periphyton: ecology, exploitation and management. CABI, Oxford

Badger MR, Price GD (2002) $\mathrm{CO}_{2}$ concentrating mechanisms in cyanobacteria: molecular components, their diversity and evolution. J Exp Bot 54:609-622

Barcelos e Ramos J, Biswas H, Schulz KG, La Roche J, Riebesell U (2007) Effect of rising atmospheric carbon dioxide on the marine nitrogen fixer Trichodesmium. Glob Biogeochem Cycles 21:1-6

Barry JP, Tyrell T, Hansson L, Plattner G-K, Gattuso J-P (2010) Atmospheric $\mathrm{CO}_{2}$ targets for ocean acidification perturbation experiments. In: Riebsel U, Fabry VJ, Hansson L, Gattusso J-P (eds) Guide to best practises for ocean acidification research and data reporting. Publications Office of the European Union, Luxembourg 
Beardall J, Giordano M (2002) Ecological implications of microalgal and cyanobacterial $\mathrm{CO}_{2}$ concentrating mechanisms and their regulation. Funct Plant Biol 29:335-347

Beardall J, Raven JA (2004) The potential effects of global climate change in microalgal photosynthesis, growth and ecology. Phycologia 43:31-45

Bianchi CN, Dando PR, Morri C (2011) Increased diversity of sessile epibenthos at subtidal hydrothermal vents: seven hypotheses based on observations at Milos Island, Aegean Sea. Adv Limnol Oceangr 2:1-31

Burkhardt S, Riebesell U (1997) $\mathrm{CO}_{2}$ availability affects elemental composition (C:N:P) of the marine diatom Skeletonema costatum. Mar Ecol Prog Ser 155:67-76

Burkhardt S, Zondervan I, Riebesell U (1999) Effect of $\mathrm{CO}_{2}$ concentration on $\mathrm{C}: \mathrm{N}: \mathrm{P}$ ratio in marine phytoplankton: a species comparison. Limnol Oceanogr 44:683-690

Burkhardt S, Amoroso G, Riebsell U, Sültemeyer D (2001) $\mathrm{CO}_{2}$ and $\mathrm{HCO}_{3}{ }^{-}$uptake in marine diatoms acclimatised to different $\mathrm{CO}_{2}$ concentrations. Limnol Oceanogr 46:1378-1391

Bustamante RH, Branch GM, Eekhout S, Robertson B et al (1995) Gradients of intertidal primary productivity around the coast of South Africa and their relationships with consumer biomass. Oecologia 102:189-201

Caldeira K, Wickett ME (2003) Anthropogenic carbon and ocean pH. Nature 425:365

Chisholm SW (1992) Phytoplankton size. In: Falkowski PG, Woodhead AD (eds) Primary productivity and biogeochemical cycles in the sea. Plenum Press, New York, pp 213-237

Cigliano M, Gambi MC, Rodolfo-Metalpa R, Patti FP, Hall-Spencer JM (2010) Effects of ocean acidification on invertebrate settlement at volcanic $\mathrm{CO}_{2}$ vents. Mar Biol 157:2489-2502

Connell SD, Russell BD (2010) The direct effects of increasing $\mathrm{CO}_{2}$ and temperature on non-calcifying organisms: increasing the potential for phase shifts in kelp forests. Proc R Soc London B 277:1409-1415

Couto RP, Neto AI, Rodrigues AS (2010) Metal concentration and structural changes in Corallina elongata (Corallinales, Rhodophyta) from hydrothermal vents. Mar Pollut Bull 60:509-514

Dias BB, Hart MB, Smart CW, Hall-Spencer JM (2010) Modern seawater acidification: the response of foraminifers to high- $\mathrm{CO}_{2}$ conditions in the Mediterranean Sea. J Geol Soc London 167:1-4

Diaz-Pulido G, Gouezo M, Tilbrook B, Dove S, Anthony KRN (2011) High $\mathrm{CO}_{2}$ enhances the competitive strength of seaweeds over corals. Ecol Lett 14:156-162

Dickson AG, Sabine CL, Christian JR (2007) Guide to best practices for ocean $\mathrm{CO}_{2}$ measurements. PICES Special Publication, 3, Sidney, Canada

Doney SC, Fabry VJ, Feely RA, Kleypas JA (2009) Ocean acidification: the other $\mathrm{CO}_{2}$ problem. Annu Rev Mar Sci 1:169-192

Edyvean EGJ, Terry IA, Picken GB (1985) Marine fouling and its effects on offshore structures in the North Sea-a review. Int Biodeterior 21:227-284

Engel A, Zondervan I, Aerts K, Beaufort L, Benthien A, Chou L, Delille B, Gattuso J-P, Harlay J, Heemann C, Hoffman L, Jacquet S, Nejstgaard J, Pizay M-D, Rochelle-Newall E, Schneider U, Terbrueggen A, Riebsell U (2005) Testing the direct effect of $\mathrm{CO}_{2}$ concentration on a bloom of the coccolithphorid Emiliania huxleyi in mesocosm experiments. Limnol Oceanogr 50:493-507

Fabricius KE, Langdon C, Uthicke S, Humphrey C, Noonan S, De'ath G, Okazaki R, Muehllehner N, Glas MS, Lough JM (2011) Losers and winners in coral reefs acclimatized to elevated carbon dioxide concentrations. Nature Clim Chang 1:165-169

Fu F-X, Warner ME, Zhang Y, Feng Y, Hutchins DA (2007) Effects of increased temperature and $\mathrm{CO}_{2}$ on photosynthesis, growth and elemental ratios of Synechococcus and Prochlorococcus (cyanobacteria). J Phycol 43:485-496

Fu F-X, Mulholland MR, Garcia NS, Beck A, Bernhardt PW, Warner ME, Sañudo-Wilhelmy SA, Hutchins DA (2008a) Interactions between changing $\mathrm{pCO}_{2}, \mathrm{~N}_{2}$ fixation, and $\mathrm{Fe}$ limitation in the marine unicellular cyanobacterium Crocosphaera. Limnol Oceanogr 53:2472-2484

Fu F-X, Zhang Y, Warner ME, Feng Y, Sun J, Hutchins DA (2008b) A comparison of future increased $\mathrm{CO}_{2}$ and temperature effects on sympatric Heterosigma akashiwo and Prorocentrum minimum. Harmful Algae 7:76-90

Giordano M, Beardall J, Raven JA (2005) $\mathrm{CO}_{2}$ concentrating mechanisms in algae: mechanism, environmental modulation, and evolution. Annu Rev Plant Biol 56:99-131

Hall-Spencer JM, Rodolfo-Metalpa R, Martin S, Ransome E, Dine M, Turner SM, Rowley SJ, Tedesco D, Buia MC (2008) Volcanic carbon dioxide vents show ecosystem effects of ocean acidification. Nature 454:96-99

Hawkins SJ, Watson DC, Hill AS, Harding SP, Kyriakides MA, Hutchinson S, Norton TA (1989) A comparison of feeding mechanisms in microphagous, herbivorous, intertidal, prosobranchs in relation to resource partitioning. J Molluscan Stud 55:151-165

Hawkins SJ, Hartnoll RG, Kain JM, Norton TA (1992) Plant-animal interactions on hard substrata in the north-east Atlantic. In: John DM, Hawkins SJ, Price JH (eds) Plant-animal interactions in the marine benthos. Oxford University Press, Oxford, pp 1-32

Hein M, Sand-Jensen K (1997) $\mathrm{CO}_{2}$ increases oceanic primary production. Nature 388:526-527

Hendriks IE, Duarte CM, Alvarez M (2010) Vulnerability of marine biodiversity to ocean acidification: a meta-analysis. Estuar Coastal Shelf Sci 86:157-164

Hepburn CD, Pritchard DW, Cornwall CE, McLeod RJ, Beardall J, Raven JA, Hurd CL (2011) Diversity of carbon use strategies in a kelp forest community: implications for a high $\mathrm{CO}_{2}$ Ocean. Glob Change Biol 17:2488-2497

Hill AS, Hawkins SJ (1990) An investigation of methods for sampling microbial films on rocky shores. J Mar Biol Assoc UK 70:77-88

Hill AS, Hawkins SJ (1991) Seasonal and spatial variation of epilithic microalgal distribution and abundance and its ingestion by Patella vulgata on a moderately exposed rocky shore. J Mar Biol Assoc UK 71:403-423

Hinga KR (2002) Effects of $\mathrm{pH}$ on coastal marine phytoplankton. Mar Ecol Prog Ser 238:281-300

Hopkinson BM, Dupont CL, Allen AE, Morel FMM (2011) Efficiency of the $\mathrm{CO}_{2}$-concentrating mechanism of diatoms. Proc Nat Acad Sci 108:3830-3837

Hoppe CJM, Langer G, Rokitta SD, Wolf-Gladrow DA, Rost B (2010) $\mathrm{On} \mathrm{CO}_{2}$ perturbation experiments: over-determination of carbonate chemistry reveals inconsistencies. Biogeosci Discuss 7:1707-1726

Huang R, Boney AD (1984) Growth interactions between littoral diatoms and juvenile marine algae. J Exp Mar Biol Ecol 81:21-45

Hurd CL, Hepburn CD, Currie KI, Raven JA, Hunter KA (2009) Testing the effects of ocean acidification on algal metabolism: considerations for experimental designs. J Phycol 45:1236-1251

Hutchins DA, Fu F-X, ZhangY WarnerME, Feng Y, Portune K, Bernhardt PW, Mullholland MR (2007) $\mathrm{CO}_{2}$ control of Trichodesmium $\mathrm{N}_{2}$ fixation, photosynthesis, growth rates and elemental ratios: implications for past, present and future ocean biogeochemistry. Limnol Oceanogr 52:1293-1304

Hutchins DA, Mulholland MR, Fu F-X (2009) Nutrient cycles and marine microbes in a $\mathrm{CO}_{2}$-enriched ocean. Oceanography 22:128-145

Iglesias-Rodriguez MD, Halloran RP, Rickaby REM, Hall IR, Colmenero-Hidalgo E, Gittins JR, Green DRH, Tyrrell T, Gibbs 
S, von Dassow P, Rehm E, Armbrust V, Boessenkoolm KP (2008) Phytoplankton calcification in a high $\mathrm{CO}_{2}$ world. Science 320:320-336

IPCC (Intergovernmental Panel on Climate Change) (2007) Working group 1 report, the physical science basis. http://ipcc-wg1.ucar. edu/wg1/wg1-report.html

Jenkins SR, Arenas F, Arrontes J, Bussell J, Castro J, Coleman RA, Hawkins SJ, Kay S, Martinez B, Oliveros J, Roberts MF, Sousa SJ, Thompson RC, Hartnoll RG (2001) European-scale analysis of seasonal variability in limpet grazing activity and microalgal abundance. Mar Ecol Prog Ser 211:193-203

Kerrison P, Hall-Spencer JM, Suggett D, Hepburn LJ, Steinke M (2011) Assessment of $\mathrm{pH}$ variability at a coastal $\mathrm{CO}_{2}$ vent for ocean acidification studies. Estuar Coastal Shelf Sci 94:129137

Kim J-M, Lee K, Shin K, Kang J-H, Lee H-W, Kim M, Jang P-G, Jang M-C (2006) The effect of seawater $\mathrm{CO}_{2}$ concentration on growth of a natural phytoplankton assemblage in a controlled mesocosm experiment. Limnol Oceanogr 51:1629-1636

Kiørboe T (1993) Turbulence, phytoplankton cell size and the structure of pelagic food webs. Adv Mar Biol 29:1-72

Kleypas JA, Yates KK (2009) Coral reefs and ocean acidification. Oceanography 22:108-117

Kranz SA, Sültemeyer D, Richter KU, Rost B (2009) Carbon acquisition in Trichodesmium: diurnal variation and effect of $\mathrm{pCO}_{2}$. Limnol Oceanogr 54:548-559

Kroeker KJ, Kordas RL, Crim RN, Singh GG (2010) Meta-analysis reveals negative yet variable effects of ocean acidification on marine organisms. Ecol Lett 13:1419-1434

Langer G, Nehrke G, Probert I, Ly J, Ziveri P (2009) Strain-specific responses of Emiliania huxleyi to changing seawater carbonate chemistry. Biogeosciences Discuss 6:4361-4383

Levitan O, Rosenberg G, Setlik I, Setlikova E, Grigel J, Klepetar J, Prasil O, Berman-Frank I (2007) Elevated $\mathrm{CO}_{2}$ enhances nitrogen fixation and growth in the marine cyanobacterium Trichodesmium. Glob Change Biol 13:531-538

Lewis E, Wallace WR (1998) Program developed for $\mathrm{CO}_{2}$ system calculations. Carbon dioxide information analysis center, Oak Ridge National Laboratory. US Department of Energy, Oak Ridge

Liu J, Weinbauer MG, Maier C, Dai M, Gattuso J-P (2010) Effect of ocean acidification on microbial diversity and on microbe-driven biogeochemistry and ecosystem functioning. Aquat Microb Ecol 61:291-305

Lombardi C, Rodolfo-Metalpa R, Cocito S, Gambi MC, Taylor PD (2010) Structural and geochemical alterations in the $\mathrm{Mg}$ calcite bryozoans Myriapora truncata under elevated seawater $p \mathrm{CO}_{2}$ simulating ocean acidification. Mar Ecol 32:211-221

Lu Z, Jiao N, Zhang H (2006) Physiological changes in marine picocyanobacterial Synechococcus strains exposed to elevated $\mathrm{CO}_{2}$ and partial pressure. Mar Biol Res 2:424-430

Mak YM, Williams GA (1999) Littorinids control high intertidal biofilm abundance on tropical, Hong Kong rocky shores. J Exp Mar Biol Ecol 233:81-94

Martin S, Gattuso J-P (2009) Response of Mediterranean coralline algae to ocean acidification and elevated temperature. Glob Change Biol 15:2089-2100

Martin S, Rodolfo-Metalpa R, Ransome E, Rowley S, Buia M-C, Gattuso J-P, Hall-Spencer JM (2008) Effects of naturally acidified seawater on seagrass calcareous epibionts. Biol Lett 4:689-692

Matsumoto M, Yohida E, Takeyama H, Matsunaga T (2000) Floating cultivation of marine cyanobacteria using coal fly ash. Appl Biochem Biotech 84-86:51-57

McNamara AE, Hill WR (2000) UV-B irradiance gradient affects photosynthesis and pigments but not food quality of periphyton. Freshwater Biol 43:649-662
Meadows PS, Williams GB (1963) Settlement of Spirorbis borealis Daudin larvae on surfaces bearing films of micro-organisms. Nature 198:610-611

Munda IM (2005) Seasonal fouling by diatoms on artificial substrata at different depths near Piran (Gulf of Trieste, Northern Adriatic). Acta Adriat 46:137-157

Nagarkar S, Williams GA (1997) Comparative techniques to quantify cyanobacteria dominated epilithic biofilms on tropical rocky shores. Mar Ecol Prog Ser 154:281-291

Nakićenović N, Swart R (2000) Special report on emissions scenarios: a special report of Working Group III of the Intergovernmental Panel on Climate Change. Cambridge University Press, Cambridge, p 599

National Research Council (2010) Ocean acidification: a national strategy to meet the challenges of a changing ocean. The National Academies Press, Washington. http://www.nap.edu/catalog/12904. html

Orr JC, Fabry VJ, Aumont O, Bopp L, Doney SC, Feely RA, Gnanadesikan A, Gruber N, Ishida A, Joos F, Key RM, Lindsay K, Maier-Reimer E, Matear R, Monfray P, Mouchet A, Najjar RG, Plattner G-K, Rodgers KB, Sabine CL, Sarmiento JL, Schlitzer R, Slater RD, Totterdell IJ, Weirig M-F, Yamanaka Y, Yool A (2005) Anthropogenic ocean acidification over the twenty-first century and its impact on calcifying organisms. Nature 437:681-686

Porzio L, Buia MC, Hall-Spencer JM (2011) Effects of ocean acidification on macroalgal communities. J Exp Mar Biol Ecol 400:278-287

Raven JA (1991) Physiology of inorganic C acquisition and implications for resource use efficiency by marine phytoplankton: Relation to increased $\mathrm{CO}_{2}$ and temperature. Plant Cell Environ 14:779-794

Raven JA, Beardall J (2003) $\mathrm{CO}_{2}$ acquisition mechanisms in algae: carbon dioxide diffusion and carbon dioxide concentrating mechanisms: In Photosynthesis in the algae. Larkum AWW, Raven JA, Douglas S (eds). Advances in photosynthesis and respiration. Series editor, Govindjee

Raven JA, Giordano M, Beardall J, Maberly S (2011) Algal and aquatic plant carbon concentrating mechanisms in relation to environmental change. Photosyn Res 109:281-296

Riebesell U (2004) Effects of $\mathrm{CO}_{2}$ enrichment on marine phytoplankton. J Oceanogr 60:719-729

Riebesell U (2008) Acid test for marine biodiversity. Nature 454:46-47

Riebesell U, Wolf-Gladrow DA, Smetacek V (1993) Carbon dioxide limitation of marine phytoplankton growth rates. Nature $361: 249-251$

Ritchie RJ (2008) Universal chlorophyll equations for estimating chlorophylls a, b, c, and d and total chlorophylls in natural assemblages of photosynthetic organisms using acetone, methanol, or ethanol solvents. Photosynthetica 46:115-1126

Rodolfo-Metalpa R, Lombardi C, Cocito S, Hall-Spencer JM, Gambi MC (2010) Effects of ocean acidification and high temperatures on the bryozoan Myriapora truncata at natural $\mathrm{CO}_{2}$ vents. Mar Ecol 31:447-456

Rodolfo-Metalpa R, Tambutté É, Houlbrèque F, Boisson F, Baggini C, Patti FP, Jeffree R, Fine M, Foggo A, Gattuso JP, HallSpencer JM (2011) Coral and mollusc resistance to ocean acidification adversely affected by warming. Nature Clim Change 1:308-312

Rost B, Riebesell U, Burkhardt S (2003) Carbon acquisition of bloomforming marine phytoplankton. Limnol Oceanogr 48:55-67

Rost B, Zondervan I, Wolf-Gladrow D (2008) Sensitivity of phytoplankton to future changes in ocean carbonate chemistry: current knowledge, contradictions and research directions. Mar Ecol Prog Ser 373:227-237 
Round FE, Crawford RM, Mann DG (1990) The diatoms-biology \& morphology of the genera. Cambridge University Press, Cambridge

Roy RN, Roy LN, Vogel KM, Porter-Moore C, Pearson T, Good CE, Millero FJ, Campbell DM (1993) The dissociation constants of carbonic acid in seawater at salinities 5 to 45 and temperatures 0 to $45{ }^{\circ} \mathrm{C}$. Mar Chem 4:249-267

Russell BD, Thompson J-A I, Falkenberg LJ, Connell SD (2009) Synergistic effects of climate change and local stressors: $\mathrm{CO}_{2}$ and nutrient-driven change in subtidal rocky habitats. Glob Change Biol 15:2153-2162

Sekar R, VenugopalanVP SatpathyKK, Nair KVK, Rao VNR (2004) Laboratory studies on adhesion of microalgae to hard substrates. Hydrobiologia 512:109-116

Shannon CE, Weaver W (1949) A mathematical theory of communication. University of Illinois Press. ISBN 0-252-72548-4

Simpson EH (1949) Measurement of diversity. Nature 163:688

Stafford R, Davies MS (2005) Spatial patchiness of epilithic biofilm caused by refuge-inhabiting high shore gastropods. Hydrobiologia 545:279-287

Stanley PM (1983) Factors affecting the irreversible attachment of Pseudomonas aeruginosa to stainless steel. Can J Microbiol 29:1493-1499

Thompson RC, Hawkins SJ, Norton TA (1998) The influence of epilithic microbial films on the settlement of Semibalanus balanoides cyprids - a comparison between laboratory and field experiments. Hydrobiologia 375(376):203-216

Thompson RC, Tobin ML, Hawkins SJ, Norton TA (1999) Problems in extraction and spectrophotometric determination of chlorophyll from epilithic microbial biofilms: towards a standard method. J Mar Biol Assoc UK 79:551-558

Thompson RC, Norton TA, Hawkins SJ (2004) Physical stress and biological control regulate the producer-consumer balance in intertidal biofilms. Ecology 85:1372-1382

Thomsen J, Gutowska MA, Saphörster J, Heinemann A, Trübenbach K, Fietzke J, Hiebenthal C, Eisenhauer A, Kürtzinger AK, Wahl M, Melzner F (2010) Calcifying invertebrates succeed in a naturally $\mathrm{CO}_{2}$ enriched coastal habitat but are threatened by high levels of future acidification. Biogeosci Discuss 7:5119-5156

Torstensson A, Chierici M, Wulff A (2011) The influence of increased temperature and carbon dioxide levels on the benthic/sea ice diatom Navicula directa. Polar Biol. doi:10.1007/s00300-0111056-4

Tortell PD, Reinfelder JR, Morel FMM (1997) Active uptake of bicarbonate by diatoms. Nature 390:243-244

Tortell PD, Rau GH, Morel FMM (2000) Inorganic carbon acquisition in coastal Pacific phytoplankton communities. Limnol Oceanogr 45:1485-1500

Tortell PD, DiTullio GR, Sigman DM, Morel FMM (2002) $\mathrm{CO}_{2}$ effects on taxonomic composition and nutrient utilisation in an Equatorial Pacific phytoplankton assemblage. Mar Ecol Prog Ser 236:37-43

Tortell PD, Payne CD, Li Y, Trimborn S, Rost B, Smith WO, Riesselman C, Dunbar RB, Sedwick DiTullioGR (2008) $\mathrm{CO}_{2}$ sensitivity of southern ocean phytoplankton. Geophys Res Lett 35:L04605. doi:10.1029/2007GL032583

Tribollet A, Atkinson MJ, Langdon C (2006) Effects of elevated $p \mathrm{CO}_{2}$ on epilithic and endolithic metabolism on reef carbonates. Glob Change Biol 12:2200-2208

Trimborn S, Wolf-Gladrow D, Ritcher K-L, Rost B (2009) The effect of $\mathrm{pCO}_{2}$ on carbon acquisition and intracellular assimilation in four marine diatoms. J Exp Mar Biol Ecol 376:26-36

Tuchman ML, Blinn DW (1979) Comparison of attached algal communities on natural and artificial substrates along a thermal gradient. Br Phycol J 14:243-251

Underwood AJ (1984) The vertical distribution and seasonal abundance of intertidal microalgae on a rocky shore in New South Wales. J Exp Mar Biol Ecol 78:199-220

Vanhaecke E, Remon J-P, Moors M, Raes F, De Rudder D, Peteghem Van (1990) Kinetics of Pseudomonas aeruginosa adhesion to 304 and 326-L stainless steel: role of cell surface hydrophobicity. Appl Environ Microbiol 56:788-795

Vizzini S, Tomasello A, Maida GD, Pirrotta M, Mazzola A, Calvo S (2010) Effect of explosive shallow hydrothermal vents on $\delta 13 \mathrm{C}$ and growth performance in the seagrass Posidonia oceanica. J Ecol 98:1284-1291

Witt V, Wild C, Anthony KRN, Diaz-Pulido G, Uthicke S (2011) Effects of ocean acidification on microbial community composition of, and oxygen fluxes through, biofilms from the Great Barrier Reef. Environ Microbiol. doi:10.1111/j.1462-2920.2011.02571.x

Wood HL, Spicer JI, Widdicombe S (2008) Ocean acidification may increase calcification rates-but at a cost. Proc Royal Soc B 275:1767-1773 